\title{
GM advisory panel is slanted, say critics
}

[WASHINGTON] The National Research Council (NRC) in Washington has come under fire over allegations that a panel set up to examine genetically modified pesticideproducing plants is slanted in favour of the biotechnology industry.

The panel is investigating the risks and benefits of such plants and examining their federal regulation. The NRC, an arm of the National Academy of Sciences, received 320 letters on the panel's composition in a public comment period that ended last week. Most of these - 268 - were negative, with many complaining that the 12 -member group includes too many people sympathetic to the biotechnology industry.

In a letter to the NRC, the Union of Concerned Scientists (UCS) and six other groups say that the panel is "weighted with molecular and agricultural scientists", to the exclusion of specialists in food allergies, soil microbiology and genetic outcrossing to wild and weedy relatives of engineered crops. "[The panel] wasn't even close in terms of balance," says Margaret Mellon, director of agriculture and biotechnology at the UCS.

The NRC plans to respond to the letters this week by announcing the appointment to the panel of Rebecca Goldburg, a senior scientist at the Environmental Defense Fund. It will also announce the resignation of Brian Staskawicz, a professor of plant biology at the University of California, Berkeley.

Staskawicz was a signatory to a controversial \$25 million deal between the university and Novartis, in which the life sciences company is funding research in his department (see page 5). He resigned voluntarily last month, says E. William Colglazier, NRC executive officer.

"Since we [at NRC] are only advisory... the only thing that really counts is our credibility, how objective we are," says Colglazier. "We take that very seriously [in] trying to put together a very expert committee" that is balanced and deals seriously with potential conflicts of interest, he says.

Colglazier says that the remaining members of the panel are being vetted for the extent to which their income is generated from sources that have a vested interest in the outcome of the study.

Critics have also questioned the current interests of two former officials of the Environmental Protection Agency (EPA) who are on the panel. One, Stanley Abramson, now works at a major Washington law firm representing companies seeking approval for genetically engineered agricultural products and defending products before government agencies and the courts.

The other, Fred Betz, represents biotechnology companies applying to EPA for registration of plants genetically engineered to produce pesticides. Betz says his involvement does not entail an "irreconcilable" conflict of interest. "Quite the contrary," he says. "The fact that [my] firm is working with the industry and with EPA [puts me in] a unique position to have a perspective on what's working and what may not be working in terms of the regulatory framework."

The NRC report is being drafted at a time when the EPA is finalizing the regulations for controlling the registration of pesticideproducing genetically modified plants. A coalition of 11 scientific societies, including the American Society for Microbiology, complained vociferously in 1996 that the EPA policy was "scientifically indefensible" in targeting genetically engineered plants for regulation (see Nature 382, 485; 1996).

The NRC says that the 1996 report helped spur it to undertake the study. It is financing the study from its endowment, in contrast to most of its studies, which are paid for by the government.

Meredith Wadman

\section{Australians seek international allies in battle over uranium mine}

[SYDNEY] Australia's environment minister, Robert Hill, has launched an international battle to stop Kakadu National Park being named an endangered World Heritage site. The dispute centres on Jabiluka uranium mine, which is being developed - with Hill's approval - on the park's border.

Last week, the small Australian Democrat party led a Senate defeat of the Coalition government, by winning approval for a committee of inquiry to investigate the government's process for approving the Jabiluka project. Democrat Senator Lyn Allison, chair of the committee, says the environmental impact assessment Hill used lacked independent peer review by scientists.

According to leaked documents, Hill is exerting diplomatic pressure on Unesco member countries to vote against the 'endangered' recommendation when the full World Heritage Committee meets in July.

Hill's campaign is based on challenges to assessments by two Unesco advisory bodies: the World Conservation Union (on environmental effects) and the International Commission on Monuments and Sites (on cultural factors). The credibility of the UN agency itself is also being questioned (see Nature 396, 606; 1998 \& 397, 287; 1999).

He is relying on a rebuttal of the findings of a group of scientists from Australian

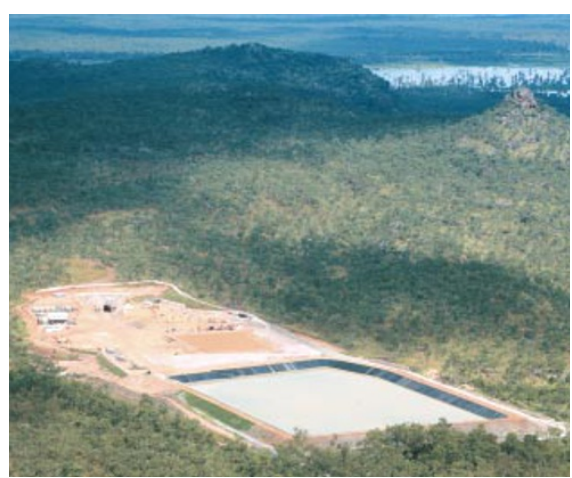

Mine of disinformation? Opponents question the accuracy of each other's reports on Jabiluka.

National University (ANU), led by hydrologist Bob Wasson. The ANU group had found that there was a significant risk, during unusually severe rainfall, of leakage into park wetlands of radioactivity from ore stockpiles, and from dams planned to contain tailings from the milling of ore.

The rebuttal Hill is citing criticizes the ANU conclusion and claims that "natural values" are not threatened. The unsigned report was prepared "with assistance from experts" at the Commonwealth Scientific and Industrial Research Organization, the Universities of Melbourne and New South Wales and the Bureau of Meteorology.
But the main thrust of Hill's criticisms has been directed at local Aborigines, the Mirrar people. They oppose drilling of the inclined shaft of the mine towards the rich ore body, claiming that this threatens their culture, as it approaches a sacred site. Hill has dismissed them as traditional owners of "a tiny fraction" the park's 20,000 square kilometres. He says that their wishes "would detrimentally affect the majority".

Like Hill, Aboriginal and environmental activists are campaigning internationally. Two weeks ago the $\mathrm{A} \$ 100,000$ (US\$65,000) Goldman Prize for environmental advocacy was awarded to senior traditional owner Yvonne Margarula and to Jacqui Katona, executive officer of the Mirrar organization, the Gundjehmi Aboriginal Corporation.

Meanwhile, Hill and science minister Nick Minchin have approved the development of Australia's fourth uranium mine, at Beverley in South Australia, the first to use the process of in-situ leaching.

The government's claim that "the waste will remain isolated from the biosphere throughout time" has been contested by the Australian Conservation Foundation. The foundation says similar uranium mines in Europe and the United States "have resulted in widespread adverse groundwater impacts and contamination". Peter Pockley 